\title{
Physiological responses of Brazilian amphibians to an enzootic infection of the chytrid fungus Batrachochytrium dendrobatidis
}

\author{
Rafael P. Bovo ${ }^{1, *}$, Denis V. Andrade ${ }^{1}$, Luís Felipe Toledo ${ }^{2}$, Ana V. Longo ${ }^{3}$, \\ David Rodriguez ${ }^{4}$, Célio F. B. Haddad ${ }^{1}$, Kelly R. Zamudio ${ }^{3}$, C. Guilherme Becker ${ }^{1}$ \\ ${ }^{1}$ Departamento de Zoologia, c. p. 199, Universidade Estadual Paulista, 13506-900, Rio Claro, SP, Brazil \\ ${ }^{2}$ Laboratório de História Natural de Anfíbios Brasileiros (LaHNAB), Departamento de Biologia Animal, Instituto de Biologia, \\ Universidade Estadual de Campinas, Rua Monteiro Lobato, 255, 13083-862, Campinas, SP, Brazil \\ ${ }^{3}$ Department of Ecology and Evolutionary Biology, Cornell University, Ithaca, NY 14853, USA \\ ${ }^{4}$ Department of Biology, Texas State University, San Marcos, TX 78666, USA
}

\begin{abstract}
Pathophysiological effects of clinical chytridiomycosis in amphibians include disorders of cutaneous osmoregulation and disruption of the ability to rehydrate, which can lead to decreased host fitness or mortality. Less attention has been given to physiological responses of hosts where enzootic infections of Batrachochytrium dendrobatidis $(B d)$ do not cause apparent population declines in the wild. Here, we experimentally tested whether an enzootic strain of $B d$ causes significant mortality and alters host water balance (evaporative water loss, EWL; skin resistance, $R_{\mathrm{s}}$ and water uptake, WU) in individuals of 3 Brazilian amphibian species (Dendropsophus minutus, $\mathrm{n}=19$; Ischnocnema parva, $\mathrm{n}=17$; Brachycephalus pitanga, $\mathrm{n}=15$ ). Infections with enzootic $B d$ caused no significant mortality, but we found an increase in $R_{\mathrm{s}}$ in 1 host species concomitant with a reduction in EWL. These results suggest that enzootic $B d$ infections can indeed cause sub-lethal effects that could lead to reduction of host fitness in Brazilian frogs and that these effects vary among species. Thus, our findings underscore the need for further assessment of physiological responses to $B d$ infections in different host species, even in cases of sub-clinical chytridiomycosis and long-term enzootic infections in natural populations.
\end{abstract}

KEY WORDS: Chytridiomycosis - Amphibian declines · Fitness - Evaporative water loss · Water uptake $\cdot$ Amphibian skin $\cdot$ Mortality

\section{INTRODUCTION}

The fungal pathogen Batrachochytrium dendrobatidis $(B d)$ causes chytridiomycosis and has led to amphibian population declines and extinctions in several parts of the globe (Berger et al. 1998, Lips et al. 2008, Vredenburg et al. 2010). Sub-lethal chytridiomycosis, however, is common where $B d$ is enzootic, such as in Brazil's Atlantic Forest, where multiple $B d$ strains have infected several hosts (Valencia-Aguilar et al. 2015) since at least the late 1800s (Rodriguez et al. 2014). Studies of $B d$ epidemiology in Brazil are on the rise (Becker \& Zamudio 2011, Becker et al. 2014, 2015, Lambertini et al. 2016, Ruggeri et al. 2015, Valencia-Aguilar et al. 2015), but to date no records of amphibian declines in Atlantic Forest frogs have been attributed to $B d$ (Toledo et al. 2006, Haddad et al. 2013, James et al. 2015). Because the Atlantic Forest harbors $\sim 10 \%$ of all described amphibian species (Haddad et al. 2013, Toledo et al. 2014, IUCN 
2015), experimentally testing the effect of locally isolated $B d$ on both mortality and physiological responses of local host species is critical for biodiversity conservation.

Clinical infections of $B d$ often impair amphibians from maintaining adequate homeostasis and directly impact host physiological and functional responses (Voyles et al. 2009, Salla et al. 2015). Specifically, Bd infection causes hyperkeratosis (skin thickening) and impairs host ability to absorb and regulate body fluids, leading to electrolyte imbalance and cardiac arrest in infected hosts (Voyles et al. 2011). Skin permeability is critically important in regulating water transport and exchange of electrolytes and respiratory gases in amphibians (Wells 2007, Hillman et al. 2009, Voyles et al. 2011). In cases of aclinical chytridiomycosis (i.e. when hosts do not show gross pathological changes in the superficial epidermis; Voyles et al. 2011), the potential impairments in physiological function remain, for the most part, unmeasured (but see also Salla et al. 2015). However, previous studies indicate that even under aclinical conditions, $B d$ may interfere with host water balance (Carver et al. 2010, Wardziak et al. 2013). If that is the case, even minor shifts in host osmoregulation - a physiological process intimately associated with amphibian life history, habitat use, and evolutionary ecology - could lead to long-term decreases in host population fitness.

A number of studies have investigated the impact of chytridiomycosis on host water balance (Voyles et al. 2009, Carver et al. 2010, Voyles 2011, Campbell et al. 2012, Wardziak et al. 2013). Water balance parameters are particularly relevant in amphibians due to their highly permeable skin and the associated risk of incurring excessive evaporative water loss (EWL; Shoemaker et al. 1992, Spotila et al. 1992, Lillywhite 2006). While laboratory studies have shown impairments of normal skin functions in $B d$-infected amphibians, the magnitude of these effects across hosts depends on a complex array of factors, including differences in $B d$ strains (Gahl et al. 2012), previous exposure of the host (Murphy et al. 2011), host life history (Gervasi et al. 2013), and host susceptibility (Searle et al. 2011). It is uncertain whether low infection intensities, such as those in localities where $B d$ is an enzootic pathogen, can significantly interfere with EWL rates and/or influence the rates of water uptake (WU) through the ventral skin, and whether such effects vary among host species.

In this study, we experimentally tested whether infection by an enzootic strain of Batrachochytrium dendrobatidis causes (1) significant mortality and (2) alters water balance in 3 amphibian species native to Brazil's Atlantic Forest. Specifically, we tested whether experimental $B d$ infections affected 3 physiological parameters key to host water balance: (1) EWL, (2) skin resistance $\left(R_{\mathrm{s}}\right)$, and (3) WU. If endemic $B d$ infection is detrimental for Brazilian amphibians, we would expect to observe either some evidence of disease-associated mortality (clinical chytridiomycosis) or some evidence of sub-clinical pathophysiology that may compromise host osmoregulatory capabilities.

\section{MATERIALS AND METHODS}

\section{Study species}

We captured adult amphibians of 3 species in October 2012 at Parque Estadual da Serra do Mar-Núcleo Santa Virginia, municipality of São Luiz do Paraitinga, state of São Paulo, Brazil $\left(23.35^{\circ} \mathrm{S}, 45.16^{\circ} \mathrm{W}\right)$. Dendropsophus minutus has aquatic larvae, breeds in aquatic habitats, and occupies the emergent vegetation at the edge of water bodies. Ischnocnema parva and Brachycephalus pitanga deposit eggs on land, undergo direct development, and are active on the forest leaf-litter. By using wild-caught amphibians in laboratory experimental infections, we are not able to control for age, previous exposure, and potential acquired resistance (McMahon et al. 2014); however, randomly assigning individual hosts for each treatment can minimize these uncontrolled factors.

\section{Experimental design}

We treated field-collected animals with itraconazole $0.01 \%$ for $7 \mathrm{~d}$ to ensure study organisms were $B d$-negative prior to the beginning of the experiment (Pessier \& Mendelson 2010, Moreno et al. 2015); treated hosts all tested negative prior to experimental infections. We cultured an enzootic $B d$ strain isolated from Minas Gerais, Brazil (CLFT 023; Schloegel et al. 2012, Longo et al. 2013) on tryptone agar Petri plates at $\sim 19^{\circ} \mathrm{C}$ for $7 \mathrm{~d}$. We harvested $B d$ by flooding plates with distilled water and waiting $\sim 3 \mathrm{~h}$ for zoospore release. The strain used in experiments belongs to the global panzootic lineage (GPL), a highly virulent strain causing amphibian declines and extinctions in several regions of the globe (Rosenblum et al. 2013). In Brazil, it has been present for at least a century (Rodriguez et al. 2014). We then pooled inoculum 
from plates and quantified zoospores with a hemocytometer.

We added 4 conspecific amphibians to rectangular experimental units measuring $40 \times 29 \times 13.5 \mathrm{~cm}$ and kept temperatures at $19.74^{\circ} \mathrm{C}(0.55 \mathrm{SD})$. These temperature records were measured by a Hobo ${ }^{\circledR}$ data logger at 30 min intervals and on a $12 \mathrm{~h}$ light: $12 \mathrm{~h}$ dark cycle. Each experimental unit consisted of a plastic terrarium with terrestrial habitat covering one end of the container (i.e. autoclaved moist sphagnum) and aquatic habitat covering the other end of the container (i.e. $250 \mathrm{ml}$ of $\mathrm{Bd}$ inoculum, $10^{6} \mathrm{zoo}-$ spores total, in the treatment group or $250 \mathrm{ml}$ of distilled water in the control group).

We monitored amphibians daily and fed them pinhead crickets ad libitum. We swabbed all individuals after $18 \mathrm{~d}$ of exposure, a period encompassing several replication cycles of the pathogen (Longcore et al. 1999). Even though timing of $B d$ life-cycle depends on the isolate (Lambertini et al. 2016) and temperature (Murphy et al. 2011), $18 \mathrm{~d}$ is often enough time for animals exposed to very high zoospore counts to show signs of lethargy or mortality (Savage \& Zamudio 2011, Gahl et al. 2012), thus also likely showing alterations in host physiology. We swabbed the single individual that died during the experiment and removed it from the experimental unit; water balance parameters were not measured for this individual. We tested samples for $B d$ in duplicate using Taqman quantitative PCR (qPCR) (Boyle et al. 2004, Lambertini et al. 2013) with CLFT 023 standards of $0.1,1,10,100$, and 1000 zoospore genomic equivalents (GE) to determine the infection intensity of $B d$ in each amphibian host. We used a total of 51 amphibians in downstream water balance analyses (Table 1).

\section{Measurements of host physiological responses}

All physiological measurements were taken within a window of $4 \mathrm{~d}$ following Day 18 post-inoculation. Prior to measuring evaporative water loss, we held animals in individual PVC containers $(4 \mathrm{~cm}$ diameter) with $0.5 \mathrm{~cm}$ of water, in a climate-controlled chamber (122FC model, Eletrolab) at $20^{\circ} \mathrm{C}$ for $1 \mathrm{~h}$ to ensure that they were fully hydrated at the beginning of the experiment. Immediately after this period, each frog was carefully blotted with paper tissue, its urinary bladder was emptied by gently pressing the abdomen, and body mass was recorded $( \pm 0.0001 \mathrm{~g})$. We placed each individual frog in a circular PVC chamber ( $8 \mathrm{~cm}$ diameter) connected to an automated open flow system that measures EWL. A pump combined to a mass flow meter (SS-3 Subsampler, Sable Systems) provided stable airflow current of $21.66 \mathrm{~cm}^{3} \mathrm{~s}^{-1}$, with relative humidity (RH) controlled at $30 \%$ by a RH/Dewpoint Controller (DG-4, Sable Systems). Airflow was directed into the experimental chamber, and relative humidity of excurrent air was continuously monitored by a water vapor analyzer (RH-300 RH/Dewpoint Analyzer, Sable Systems). All equipment was maintained inside the climate-controlled chamber at the experimental temperature of $20^{\circ} \mathrm{C}$.

Changes in relative humidity were interfaced to a computer by an analog/digital unit (UI2, Sable Systems) and recorded/analyzed using the Expedata software (Sable Systems). The amount of water lost, per animal, per unit of time, was calculated from the increment in water content between the airflow upstream (controlled at $30 \% \mathrm{RH}$ ) and downstream of the animal chamber (measured using the water vapor analyzer). Measurements lasted for up to 30 min per individual, and for quantitative estimates we selected a period of steady-state readings lasting for at least $10 \mathrm{~min}$, typically during the second half of the measurement period. For each animal, the total EWL was then corrected for unit area of exposed skin surface and expressed as $\mu \mathrm{g} \mathrm{H}_{2} \mathrm{O} \mathrm{cm}^{-2} \mathrm{~s}^{-1}$. We estimated the exposed surface area of individual amphibians on the basis of their body mass (McClanahan \& Baldwin 1969, Young et al. 2005) and the posture assumed by the animals, which were monitored visually during the experiments. EWL through the respiratory system was assumed to be negligible (Spotila \& Berman 1976, Bentley \& Yorio 1979, Wygoda 1984) and not considered in our estimates.

Table 1. Summary of number of individuals, body mass (for all frogs), and infection loads (for Bd-infected individuals only) for the 3 host species. Data are means \pm SD. Uninf: uninfected; GE: genomic equivalents

\begin{tabular}{|lccccc|}
\hline Species & $\begin{array}{c}\text { Total } \\
\text { (no.) }\end{array}$ & $\begin{array}{c}\text { Bd-infected } \\
\text { (no.) }\end{array}$ & $\begin{array}{c}\text { Uninf. control } \\
\text { control (no.) }\end{array}$ & $\begin{array}{c}\text { Body mass } \\
\text { (g) }\end{array}$ & $\begin{array}{c}\text { Bd-infection } \\
\text { loads (GE) }\end{array}$ \\
\hline Dendropsophus minutus & 19 & 12 & 7 & $0.51 \pm 0.07$ & $22.37 \pm 49.44$ \\
Ischnocnema parva & 17 & 10 & 7 & $0.32 \pm 0.13$ & $46.50 \pm 60.74$ \\
Brachycephalus pitanga & 15 & 8 & 7 & $0.2 \pm 0.04$ & $19.75 \pm 45.75$ \\
\hline
\end{tabular}


Table 2. Effects of $B d$ infection on water balance in 3 Brazilian anuran species from the Atlantic Forest. Significant effects are highlighted in bold

\begin{tabular}{|lcc|}
\hline Variable & $F$ & $\mathrm{p}$ \\
\hline Evaporative water loss $\left(\mu \mathrm{g} \mathrm{cm}^{-2} \mathrm{~s}^{-1}\right)$ & & \\
Treatment & 14.73 & $\mathbf{< 0 . 0 0 1}$ \\
Species & 9.34 & $<\mathbf{0 . 0 0 1}$ \\
Species $\times$ Treatment & 2.68 & 0.079 \\
Body mass & 2.08 & 0.155 \\
Skin resistance $\left(\mathrm{s} \mathrm{cm}^{-1}\right)$ & & \\
Treatment & 7.76 & $<\mathbf{0 . 0 1}$ \\
Species & 17.22 & $\mathbf{< 0 . 0 0 0 1}$ \\
Species $\times$ Treatment & 4.05 & $<\mathbf{0 . 0 5}$ \\
Body mass & 0.03 & 0.853 \\
Water uptake $\left(\mu \mathrm{cm}^{-2} \mathrm{~s}^{-1}\right)$ & & \\
Treatment & & \\
Species & -2.24 & $<\mathbf{0 . 0 5}$ \\
Species $\times$ Treatment & -0.05 & 0.956 \\
Body mass & -0.43 & 0.668 \\
& 1.18 & 0.246 \\
\hline
\end{tabular}

For each individual frog that had its EWL rate measured, we also measured a similar-sized 3\% agar replica to determine boundary layer resistance, which allowed us to calculate skin resistance to water efflux $\left(R_{\mathrm{s}}\right.$ expressed as s cm${ }^{-1}$ ) (see Shoemaker et al. 1992, Young et al. 2005). Total resistance to water efflux $\left(R_{\mathrm{t}}\right)$ was calculated as the sum of skin $\left(R_{\mathrm{s}}\right)$ and boundary layer $\left(R_{\mathrm{b}}\right)$ resistances and is expressed in terms of a mass transfer coefficient, i.e. as centimeters of water movement per second. The reciprocal of this coefficient is termed the resistance of water movement ( $\mathrm{s} \mathrm{cm}^{-1}$; Shoemaker et al. 1992, Young et al. 2005).

Immediately after the EWL tests, each individual was placed in a Petri dish with water to a depth of $0.5 \mathrm{~cm}$, sufficient to cover the ventral abdominal region (Cree 1988). Frogs were carefully blotted with paper tissue and weighed $( \pm 0.0001 \mathrm{~g}) 6$ consecutive times at 2 min intervals. We calculated WU from the linear regression between body mass increments against time. Then, using the estimated surface area in contact with the water (same equations as above), we calculated the rate of WU per unit of area and expressed it as $\mu \mathrm{g} \mathrm{H}_{2} \mathrm{O} \mathrm{cm} \mathrm{cm}^{-2} \mathrm{~s}^{-1}$. WU was not determined for $B$. pitanga individuals due to their diminutive body size, which precluded accurate measurements.

\section{Statistical analyses}

We compared mortality rates between treatment and control groups for each species using Wilcoxon tests. We compared host physiological responses
(EWL, $R_{\mathrm{s}}$ and WU) between $B d$ infection treatments ( $B d$-infected and $B d$-uninfected) using general linear models (GLM) with standard least squares. We included in the model treatment crossed with species and the main effect of body mass. We performed GLMs to test the effect of $B d$ infection loads on each water balance parameter (EWL, $R_{\mathrm{s}}$ and WU), independently for each species. We $\log _{10}$-transformed $B d$ infection load data for this analysis. We did not include prevalence data in the analyses because all amphibians in the experimental infection tested positive for $B d$.

\section{RESULTS}

$B d$-infected hosts showed no significant increase in mortality when compared to uninfected controls; only 1 individual frog died during the course of the experiment (B. pitanga; $B d$-infected; log-rank $\chi^{2}=$ 0.875, df $=1, \mathrm{p}=0.349$ ). However, the treefrog Dendropsophus minutus showed a significant increase in $R_{\mathrm{s}}$ associated with a decreased EWL (Table 2, Fig. 1). No such changes were observed for the other 2 species (Table 2, Fig. 1). WU did not differ significantly between $B d$-infected and uninfected hosts in any of the species tested (Table 2, Fig. 1).

All individuals exposed to $B d$ tested positive at $18 \mathrm{~d}$ post initial exposure but showed consistently low infection loads (Fig. A1 in the Appendix). Bd infection loads did not differ among species (KruskalWallis $H=2.68$, df $=2, \mathrm{p}=0.26$, Fig. A1, Table 1), and we also found no significant relationship between water balance measures and $B d$ infection loads after Bonferroni correction for multiple comparisons.

\section{DISCUSSION}

The global pandemic Bd strain (GPL-2) CLFT 023, enzootic in the Atlantic Forest for at least $100 \mathrm{yr}$ (Rodriguez et al. 2014), did not cause significant mortality in any of our focal host species under experimental conditions but led to shifts in the water balance of 1 out of 3 of the tested species. Therefore, our results underscore that enzootic $B d$ GPL may cause negative effects in wild anuran populations, even in cases when hosts may have potentially evolved resistance or tolerance to the focal $B d$ isolate (Briggs et al. 2005, Carey et al. 2006, Woodhams et al. 2011, Rodriguez et al. 2014). Indeed, the observed host infection loads in our experimental study were 2 orders of magnitude lower than loads observed in 

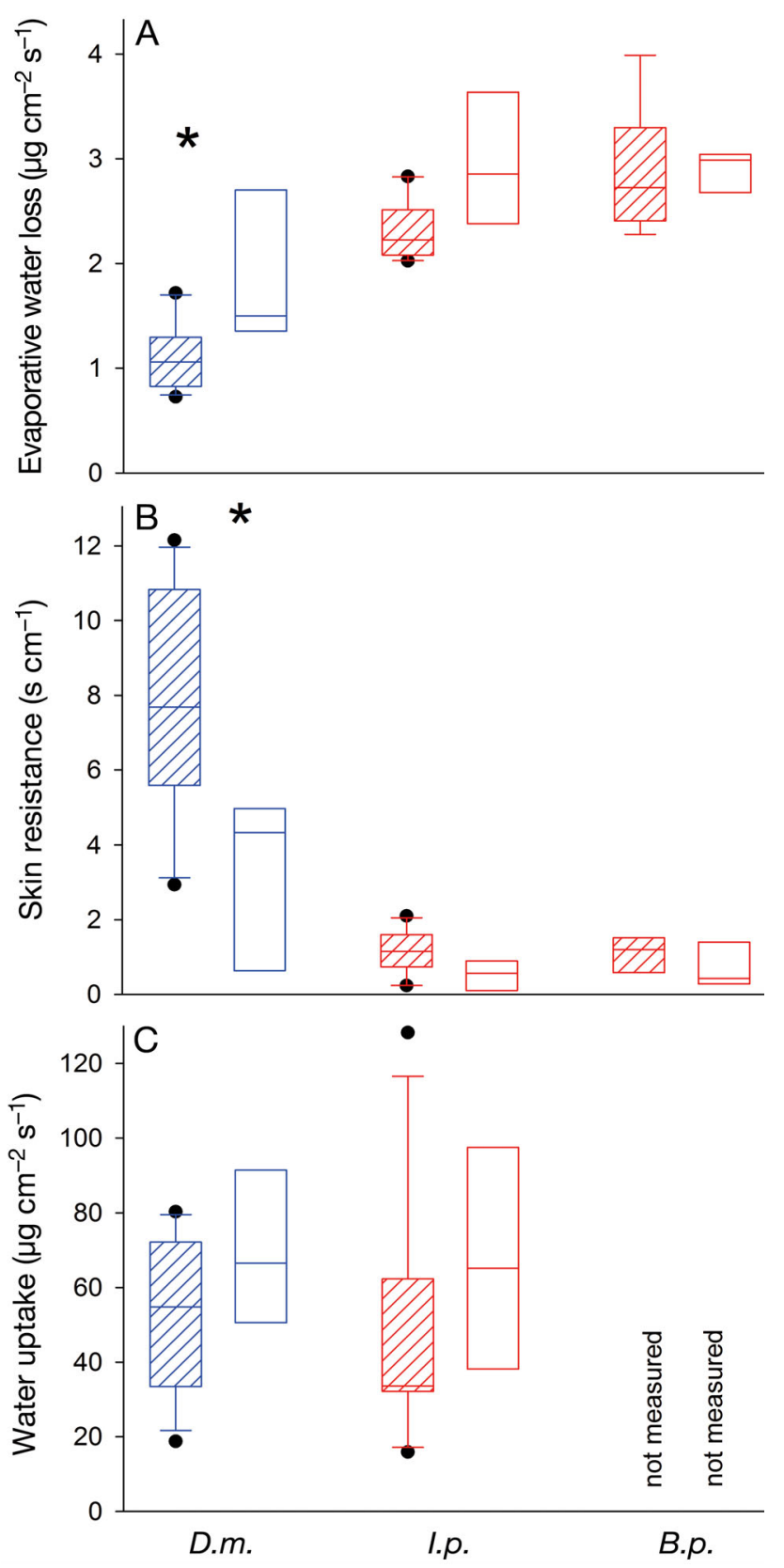

Fig. 1. Water balance parameters measured in our 3 focal host species; $B d$-infected animals (striped boxes) and uninfected controls (open boxes). Horizontal lines: medians; boxes: interquartile ranges; whiskers: minimum and maximum values, excluding outliers (dots). Asterisks denote significant differences between $B d$-infected and control treatments. Blue: host species with aquatic larval development; red: terrestrial species with direct development. D.m.: Dendropsophus minutus; I.p.: Ischnocnema parva; B.p.: Brachycephalus pitanga

clinical chytridiomycosis (Vredenburg et al. 2010). Moreover, our results show that these effects vary with species, although the mechanisms for these differences are not yet known.
For the species whose water balance was disrupted by $B d$ infection (Dendropsophus minutus), the main physiological response was an increase in $R_{\mathrm{s}}$ associated with a reduction in EWL. Whether such response was linked to $B d$-induced disruptions in skin morphology (see Voyles et al. 2011) remains to be investigated, but this is a likely mechanism. We expected that $B d$ infection would lead to changes in WU because, in most anurans, uptake and regulation occur through specialized cells and tissues in the ventral region (Larsen et al. 1987, Wells 2007), and this is precisely the body region most severely infected by $B d$ (Berger et al. 1998, 2005, Pessier et al. 1999). Although disruptions in amphibian osmoregulation have not been clearly linked to hyperplasia or hyperkeratosis, our data suggest that some physiological aspects involving skin functions are compromised upon infection. None of our study species showed significant changes in WU as a result of infection (including D. minutus); however, we did find a trend of reduced WU in all infected species we measured, a pattern previously reported for other $B d$-infected amphibians (Carver et al. 2010, Wardziak et al. 2013). Therefore, the 3 physiological parameters we measured changed in the direction expected in cases of clinical chytridiomycosis and thus may contribute to sub-lethal effects in an enzootic host-pathogen system. Our findings also support the epidermal dysfunction hypothesis (RollinsSmith et al. 2009, Voyles et al. 2009, Carver et al. 2010), which suggests that $B d$ disrupts hosts rehydration and osmoregulatory processes.

Disruption in host rehydration and osmotic balance can also result in behavioral changes such as lethargic posture (Carver et al. 2010). Although we did not measure behavioral responses to $B d$ infections, we did not observe any obvious changes in posture during the course of the experiment and while measuring host physiological responses. An interesting question is whether aquatic and terrestrial hosts show different physiological responses as a result of infection. In general, aquatic amphibians are more likely to be naturally infected with $B d$ than terrestrial species due to greater exposure to the pathogen in aquatic reservoirs (Longcore et al. 2007, Rowley 2007, Bancroft et al. 2011). What is less clear is whether aquatic species exhibit faster acquired resistance and long-term adaptations due to prolonged contacts with the pathogen. Previous studies show that terrestrial species (e.g. Anaxyrus boreas; Carey et al. 2006) can sometimes be more susceptible to $B d$ than fully aquatic species (e.g. Xenopus leavis; Ramsey et al. 2010). D. minutus - the only study species 
with aquatic larval development - was the only species showing significant changes in water balance parameters as a result of $B d$ infection. This could be explained, at least in part, by the fact that our enclosures mimicked both terrestrial and aquatic habitats, and thus more terrestrial species could be able to behaviorally escape infection in the terrestrial environment. Nevertheless, our 2 focal terrestrial host species (Ischnocnema parva and Brachycephalus pitanga) showed comparable low infection loads (see Fig. A1) but no significant changes in physiological responses. Further studies focusing on how physiological adaptations vary among host's life histories will provide valuable information about the effects of chytridiomycosis in the wild.

The fact that a $B d$ GPL strain isolated from Brazil did not cause significant mortality in 3 local host species definitely bodes well for the local anurofauna. Nonetheless, sub-lethal physiological changes in one of our focal species might reflect decreased fitness and lead to silent shifts in population abundances in the wild (Longo \& Burrowes 2010). For example, individuals with impaired water balance might adopt behavioral changes to restore equilibrium between water loss and uptake, consequently leading to modifications in ecological interactions (new situations of predation or competition by use of new microhabitats), thus possibly compromising fitness.

It is also possible that such changes in host osmoregulatory functions could trigger population declines in the wild under special environmental circumstances (e.g. climate variability, global warming, and drought; Burrowes et al. 2004, Pounds et al. 2006). Even though amphibian declines in Brazil have not been linked to $B d$ (see Toledo et al. 2006, Ruggeri et al. 2015), a few enigmatic and isolated population crashes of stream-breeding frogs occurred in the Atlantic Forest during the late 1970s and early 1980s (Heyer et al. 1988, Weygoldt 1989), and $B d$ infection dynamics do vary seasonally (Ruggeri et al. 2015) and across habitat types (Becker \& Zamudio 2011), suggesting that $B d$ outbreaks could indeed be a potential threat in local wild populations under specific conditions. Further studies testing how Brazilian amphibian species respond to multiple $B d$ strains under varying micro-environmental conditions will be especially fruitful for our understanding of $B d$ dynamics in nature (James et al. 2015).

Acknowledgements. We thank Nadya Pupin, Décio T. Corrêa-Filho, and Carolina Lambertini for assistance during experimental infections. Our work was funded by grants from the National Science Foundation (DDIG 1209382; DEB-
0542848); Atkinson Center for a Sustainable Future, Coordenação de Aperfeiçoamento de Pessoal de Nível SuperiorFulbright (Grant 2157-08), and Department of Ecology and Evolutionary Biology at Cornell University; São Paulo Research Foundation (FAPESP) grants \#2010/05473-6, \#2010/ 20061-6, \#2011/51694-7, \#2013/04190-9, and \#2013/574017; Conselho Nacional de Desenvolvimento Científico e Tecnológico-CNPq. Research permits were provided by Instituto Chico Mendes da Conservação da Biodiversidade-Brazil (Permits 29964-3; 17242-3), Instituto Florestal do Estado de São Paulo (Permit 260108-010.479/2012), Universidade Estadual Paulista (UNESP) Comissão de Ética no Uso de Animal (Permit 7180), US Fish \& Wildlife Services (Permit 2013MI1337329), and the Cornell University Institutional Animal Care and Use Committee (2010-0069).

\section{LITERATURE CITED}

Bancroft B, Han B, Searle C, Biga L and others (2011) Species-level correlates of susceptibility to the pathogenic amphibian fungus Batrachochytrium dendrobatidis in the United States. Biodivers Conserv 20:1911-1920

Becker CG, Zamudio KR (2011) Tropical amphibian populations experience higher disease risk in natural habitats. Proc Natl Acad Sci USA 108:9893-9898

> Becker CG, Rodriguez D, Toledo LF, Longo AV and others (2014) Partitioning the net effect of host diversity on an emerging amphibian pathogen. Proc R Soc B 281:20141796

Becker CG, Rodriguez D, Longo AV, Toledo LF, Haddad CFB, Zamudio KR (2015) Deforestation, host community structure, and amphibian disease risk. Basic Appl Ecol (in press), doi:10.1016/j.baae.2015.08.004

Bentley PJ, Yorio T (1979) Evaporative water loss in anuran amphibia: a comparative study. Comp Biochem Physiol 62A:1005-1009

Berger L, Speare R, Daszak P, Green DE and others (1998) Chytridiomycosis causes amphibian mortality associated with population declines in the rain forests of Australia and Central America. Proc Natl Acad Sci USA 95: 9031-9036

Berger L, Speare R, Skerratt LF (2005) Distribution of Batrachochytrium dendrobatidis and pathology in the skin of green tree frogs Litoria caerulea with severe chytridiomycosis. Dis Aquat Org 68:65-70

Boyle DG, Boyle DB, Olsen V, Morgan JAT, Hyatt AD (2004) Rapid quantitative detection of chytridiomycosis (Batrachochytrium dendrobatidis) in amphibian samples using real-time Taqman PCR assay. Dis Aquat Org 60:141-148

> Briggs CJ, Vredenburg VT, Knapp RA, Rachowicz LJ (2005) Investigating the population-level effects of chytridiomycosis: an emerging infectious disease of amphibians. Ecology 86:3149-3159

Burrowes PA, Joglar RL, Green DE (2004) Potential causes for amphibian declines in Puerto Rico. Herpetologica 60: $141-154$

Campbell CR, Voyles J, Cook DI, Dinudom A (2012) Frog skin epithelium: electrolyte transport and chytridiomycosis. Int J Biochem Cell Biol 44:431-434

> Carey C, Bruzgul JE, Livo LJ, Walling ML and others (2006) Experimental exposures of boreal toads (Bufo boreas) to a pathogenic chytrid fungus (Batrachochytrium dendrobatidis). EcoHealth 3:5-21

Carver S, Bell BD, Waldman B (2010) Does chytridiomycosis disrupt amphibian skin function? Copeia 487-495 
Cree A (1988) Water balance responses of the hylid frog Litoria aurea. J Exp Zool 247:119-125

Gahl MK, Longcore JE, Houlahan JE (2012) Varying responses of northeastern North American amphibians to the chytrid pathogen Batrachochytrium dendrobatidis. Conserv Biol 26:135-141

Gervasi S, Gondhalekar C, Olson DH, Blaustein AR (2013) Host identity matters in the amphibian-Batrachochytrium dendrobatidis system: fine-scale patterns of variation in responses to a multi-host pathogen. PLoS ONE 8:e54490

Haddad CFB, Toledo LF, Prado CPA, Loebmann D and others (2013) Guide to the amphibians of the Atlantic Forest: diversity and biology. Anolis Books, São Paulo

$>$ Heyer WR, Rand AS, da Cruz CAG, Peixoto OL (1988) Decimations, extinctions, and colonizations of frog populations in southeast Brazil and their evolutionary implications. Biotropica 20:230-235

Hillman SS, Withers PC, Drewes RC, Hillyard SD (2009) Ecological and environmental physiology of amphibians. Oxford University Press, Oxford

IUCN, Conservation International, NatureServe (2015) Global amphibian assesment. Available at www.amphibians. org/publications/threatened-amphibians-of-the-world/ (accessed 15.11.2015)

James TY, Toledo LF, Rödder D, Leite DS and others (2015) Disentangling host, pathogen, and environmental determinants of a recently emerged wildlife disease: lessons from the first 15 years of amphibian chytridiomycosis research. Ecol Evol 5:4079-4097

Lambertini C, Rodriguez D, Brito FB, Leite DS, Toledo LF (2013) Diagnóstico do fungo quitrídio: Batrachochytrium dendrobatidis. Herpetol Bras 2:12-17

Lambertini C, Becker CG, Jenkinson TS, Rodriguez D and others (2016) Local phenotypic variation in amphibiankilling fungus predicts infection dynamics. Fungal Ecol 20:15-21

> Larsen EH, Ussing HH, Spring KR (1987) Ion transport by mitochondria-rich cells in toad skin. J Membr Biol 99: 25-40

> Lillywhite HB (2006) Water relations of tetrapod integument. J Exp Biol 209:202-226

> Lips KR, Diffendorfer J, Mendelson III Jr, Sears M (2008) Riding the wave: reconciling the roles of disease and climate change in amphibian declines. PLoS Biol 6:e72

> Longcore JE, Pessier AP, Nichols DK (1999) Batrachochytrium dendrobatidis gen. et sp. nov., a chytrid pathogenic to amphibians. Mycologia 91:219-227

Longcore JR, Longcore JE, Pessier AP, Halteman WA (2007) Chytridiomycosis widespread in anurans of northeastern United States. J Wildl Manag 71:435-444

Longo AV, Burrowes PA (2010) Persistence with chytridiomycosis does not assure survival of direct-developing frogs. Ecohealth 7:185-195

> Longo AV, Rodriguez D, Leite DS, Toledo LF, Mendoza Almeralla C, Burrowes PA, Zamudio KR (2013) ITS1 copy number varies among Batrachochytrium dendrobatidis strains: implications for qPCR zoospore estimation of fieldcollected amphibian skin swabs. PLoS ONE 8:e59499

McClanahan L, Baldwin R (1969) Rate of water uptake through the integument of the desert toad, Bufo punctatus. Comp Biochem Physiol 28:381-389

McMahon TA, Sears BF, Venesky MD, Bessier SM and others (2014) Amphibians acquire resistance to live and dead fungus overcoming fungal immunosuppression.
Nature 511:224-227

Moreno LF, Morão P, Toledo LF (2015) Tratamento de anfíbios infectados pelo fungo quitrídio do gênero Batrachochytrium. Herpetol Bras 4:30-34

> Murphy PJ, St-Hilaire S, Corn PS (2011) Temperature, hydric environment, and prior pathogen exposure alter the experimental severity of chytridiomycosis in boreal toads. Dis Aquat Org 95:31-42

Pessier AP, Mendelson JR (eds) (2010) A manual for control of infectious diseases in amphibian survival assurance colonies and reintroduction programs. IUCN/SSC Conservation Breeding Specialist Group, Apple Valley, MN

Pessier AP, Nichols DK, Longcore JE, Fuller MS (1999) Cutaneous chytridiomycosis in poison dart frogs (Dendrobates spp.) and White's tree frogs (Litoria caerulea). J Vet Diagn Invest 11:194-199

> Pounds JA, Bustamante MR, Coloma LA, Consuegra JA and others (2006) Widespread amphibian extinctions from epidemic disease driven by global warming. Nature 439: 161-167

Ramsey JP, Reinert LK, Harper LK, Woodhams DC, RollinsSmith LA (2010) Immune defenses against Batrachochytrium dendrobatidis, a fungus linked to global amphibian declines, in the South African clawed frog, Xenopus laevis. Infect Immun 78:3981-3992

Rodriguez D, Becker CG, Pupin N, Haddad CFB, Zamudio KR (2014) Long-term endemism of two highly divergent lineages of the amphibian-killing fungus in the Atlantic Forest of Brazil. Mol Ecol 23:774-787

> Rollins-Smith LA, Ramsey JP, Reinert LK, Woodhams DC and others (2009) Immune defenses of Xenopus laevis against Batrachochytrium dendrobatidis. Front Biosci (Schol Ed) 1:68-91

Rosenblum EB, James TY, Zamudio KR, Poorten TJ and others (2013) Complex history of the amphibian-killing chytrid fungus revealed with genome resequencing data. Proc Natl Acad Sci USA 110:9385-9390

Rowley JJL (2007) Why does chytridiomycosis drive some frog populations to extinction and not others? The effects of interspecific variation in host behavior. PhD dissertation, School of Marine and Tropical Biology, James Cook University, Townsville

Ruggeri J, Longo AV, Gaiarsa MP, Alencar LRV and others (2015) Seasonal variation in population abundance and chytrid infection in stream-dwelling frogs of the Brazilian Atlantic forest. PLoS ONE 10:e0130554

Salla RF, Gamero FU, Ribeiro LR, Rizzi GM and others (2015) Cardiac adaptations of bullfrog tadpoles in response to chytrid infection. J Exp Zool A Ecol Genet Physiol 323:487-496

Savage AE, Zamudio KR (2011) MHC genotypes associate with resistance to a frog-killing fungus. Proc Natl Acad Sci USA 108:16705-16710

Schloegel LM, Toledo LF, Longcore JE, Greenspan SE and others (2012) Novel, panzootic and hybrid genotypes of amphibian chytridiomycosis associated with the bullfrog trade. Mol Ecol 21:5162-5177

Searle CL, Gervasi SS, Hua J, Hammond JI, Relyea RA, Olson DH, Blaustein AR (2011) Differential host susceptibility to Batrachochytrium dendrobatidis, an emerging amphibian pathogen. Conserv Biol 25:965-974

Shoemaker VH, Hillman SS, Hillyard SD, Jackson DC Relyea, RA, Olson DH, Blaustein AR (1992) Exchange of water, ions, and respiratory gases in terrestrial amphibians. In: Feder ME, Burggren WW (eds) Environmental 
physiology of the amphibians. University of Chicago Press, Chicago, IL, p 125-150

Spotila JR, Berman EN (1976) Determination of skin resistance and the role of the skin in controlling water loss in amphibians and reptiles. Comp Biochem Physiol A Comp Physiol 55:407-411

Spotila JR, O'Connor MP, Bakken GS (1992) Biophysics of heat and mass transfer. In: Feder ME, Burggren WW (eds) Environmental physiology of the amphibians. University of Chicago Press, Chicago, IL, p 59-80

Toledo LF, Haddad CFB, Carnaval AOQC, Britto FB (2006) A Brazilian anuran (Hylodes magalhaesi: Leptodactylidae) infected by Batrachochytrium dendrobatidis: a conservation concern. Amphib Reptile Conserv 4:17-21

Toledo LF, Becker CG, Haddad CFB, Zamudio KR (2014) Rarity as an indicator of endangerment in neotropical frogs. Biol Conserv 179:54-62

Valencia-Aguilar A, Ruano-Fajardo G, Lambertini C, Leite DS, Toledo LF, Mott T (2015) Chytrid fungus acts as a generalist pathogen infecting species-rich amphibian families in Brazilian rainforests. Dis Aquat Org 114: 61-67

Voyles J, Young S, Berger L, Campbell C and others (2009) Pathogenesis of chytridiomycosis, a cause of catastrophic amphibian declines. Science 326:582-585

Voyles J, Rosenblum EB, Berger L (2011) Interactions between Batrachochytrium dendrobatidis and its amphi- bian hosts: a review of pathogenesis and immunity. Microbes Infect 13:25-32

Vredenburg VT, Knapp RA, Tunstall T, Briggs CJ (2010) Dynamics of an emerging disease drive large-scale amphibian population extinctions. Proc Natl Acad Sci USA 107:9689-9694

> Wardziak T, Luquet E, Plenet S, Léna JP, Oxarango L, Joly P (2013) Impact of both desiccation and exposure to an emergent skin pathogen on transepidermal water exchange in the palmate newt Lissotriton helveticus. Dis Aquat Org 104:215-224

Wells KD (2007) The ecology and behavior of amphibians. Chicago University Press, Chicago, IL

- Weygoldt P (1989) Changes in the composition of mountain stream frog communities in the Atlantic mountains of Brazil - frogs as indicators of environmental deteriorations? Stud Neotrop Fauna Environ 24:249-255

Woodhams DC, Bosch J, Briggs CJ, Cashins S and others (2011) Mitigating amphibian disease: strategies to maintain wild populations and control chytridiomycosis. Front Zool 8:8-24

Wygoda M (1984) Low cutaneous evaporative water loss in arboreal frogs. Physiol Zool 57:329-337

Young JE, Christian KA, Donnellan S, Tracy CR, Parry D (2005) Comparative analysis of cutaneous evaporative water loss in frogs demonstrates correlation with ecological habits. Physiol Biochem Zool 78:847-856
Appendix

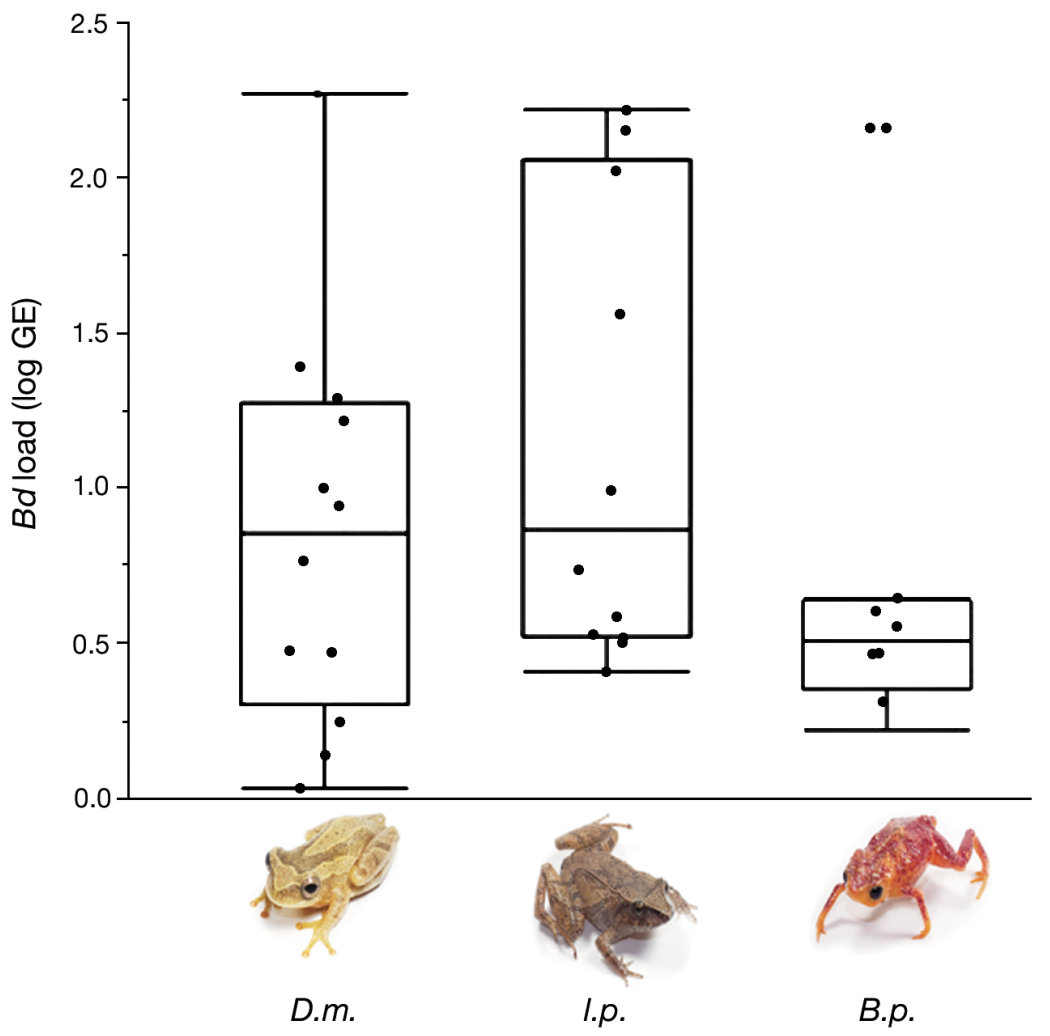

Fig. A1. Bd infection loads (log genomic equivalents [GE]) of amphibians $18 \mathrm{~d}$ post exposure. Horizontal lines: medians; boxes: interquartile ranges; whiskers: minimum and maximum values, excluding outliers. Dots represent individual $B d$ load measurements. D.m.: Dendropsophus minutus; I.p.: Ischnocnema parva; B.p.: Brachycephalus pitanga. Points denote each observation 